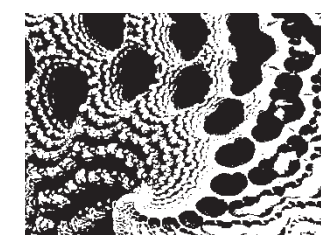

\title{
HOFSTEDE'S CULTURE VALUE SURVEY IN CROATIA: EXAMINING REGIONAL DIFFERENCES
}

Edo RAJH, Jelena BUDAK, Ivan-Damir ANIĆ Institute of Economics, Zagreb

UDK: 304.4(497.5):303.62

Prethodno priopćenje

Primlieno: 19. 2. 2015.

The purpose of this paper is to apply Hofstede's value survey in Croatia and examine regional differences in the cultural dimensions of power distance, individualism, masculinity, uncertainty avoidance and long-term orientation. Based on the large national survey data $(N=1,500)$, the scores for five dimensions were analysed at the national and sub-national regional levels. This study contributes to Hofstede's theory of culture by using the general population sample and examining regional differences. The results show that Croatia scores lower on power distance, is a moderately high individualistic country, has a tendency towards "feminine" culture and has a lower level of long-term orientation, which are all characteristics of developed countries. However, the value of uncertainty avoidance is high, which is a characteristic of post-transition economies. The analysis at regional level in Croatia reveals that Croatia is homogeneous with respect to Hofstede's dimensions of national culture. The cluster analysis was performed using dimensions of national culture for Croatia. Among the identified clusters differences exist in gender and age, while there are no significant differences related to the level of education. Implications for managers and policy makers are discussed in the paper.

Keywords: Hofstede, cultural dimensions, Croatia, regional differences 
The process of globalization and increased economic interdependence among countries and regions has brought a wealth of potential for cross-cultural studies. Culture affects people's lives, attitudes, beliefs, their work and achievements, and particularly cross-cultural management (Kaasa, Vadi, \& Varblane, 2014). Culture can be critical for success or failure of business, while cultural differences may explain why management's practices suited for one cultural environment may bring about undesirable consequences in another (Mooij \& Hofstede, 2002; Kustin, 2006; Treven, Mulej, \& Lynn, 2008). Besides the extensive research about cross-country differences, within-country differences have just recently received more attention in the literature (Hofstede, Hofstede, \& Minkov, 2010; Minkov \& Hofstede, 2014; Kaasa et al., 2014). However, there are conflicting results in the literature, and several studies call for further investigation of cultural differences, particularly at regional level.

The objective of this paper is to apply Hofstede's value survey in Croatia (the Values Survey Module 1994, VSM-94, Hofstede, 1994) and to empirically examine regional differences within Croatia. More specifically, this paper seeks to identify scores for five dimensions of national culture for Croatia and to examine whether there are regional differences in Hofstede's cultural dimensions in Croatia. Our study is based on the widely used original model of Hofstede, which claims that the most important cultural issues can be captured by the following five cultural dimensions: Power Distance (PDI), Individualism (IDV), Masculinity (MAS), Uncertainty Avoidance (UAI), and Long-Term Orientation (LTO). The survey captures individuals' perceptions of their daily work environment resulting in specific ways of dealing with everyday problems as well as those expressed in business. Scores for each cultural dimension are produced at the national and sub-national level for five Croatian regions, and results are discussed in the policy context.

This study contributes to Hofstede's theory of culture. Originally, Hofstede used data to study employees' work-related values in the subsidiaries of a multinational corporation in order to derive cultural dimensions (Hofstede, 1980; Hofstede, 1997), while this model can be applied also at the general population level, as a number of replicative studies confirm (Hofstede et al., 2010). We add value by the analysis of regional differences in five dimensions of Hofstede's national culture concept. Since past research suggests that differences in ethnic identity, historical background, geographical characteristics (e.g., seaside or mountain regions) may cause significant cultural variability between the regions 
DRUŠ. ISTRAŽ. ZAGREB GOD. 25 (2016), BR. 3 STR. 309-327

RAJH, E., BUDAK, J., ANIC, I.-D.: HOFSTEDE'S CULTURE... inside one country (Kaasa et al., 2014), our motive is to examine if five dimensions of culture vary across regions in Croatia. Furthermore, in this study we provide Hofstede's indices for Croatia, as such an analysis has not been produced on a national representative sample since the 1970 s (i.e. data for Croatia were extrapolated based on the research conducted in ex-Yugoslavia). Conducting a survey on a large nationally representative sample of citizens in Croatia contributes to the body of the national research.

Several managerial and public policy implications might be derived from this study. Recognizing cultural differences helps improve the business environment (Treven et al., 2008; Budak, Rajh, \& Stubbs, 2013). It allows business managers and policy decision-makers and governments to understand people's attitudes better, improve their managerial and policy skills, and design management concepts and business strategies more successfully. As firms expand nationally, management should understand how regional cultural differences might affect the process of doing business in different regions. Lessons learned on cultural characteristics are interesting from the business point of view, and here we argue they could be instructive for general policy management as well, for personal development and society as a whole. Our findings are expected to contribute to the ongoing research debate on culturally (non-) homogenous nations and regions (Minkov \& Hofstede, 2012; Minkov \& Hofstede, 2014; Kaasa et al., 2014). Our results also reveal whether Croatian regions are heterogeneous or more homogenous, which could be useful for the application of standardization vs. customization marketing approach applied at the company level (Mooij \& Hofstede, 2002), and for designing regional policy and socio-economic development policy. Finally, this research contributes to the recent debate on regional disparities in Croatia (e.g. Bačić \& Šišinački, 2014).

The paper is organized as follows. A literature review on Hofstede's national culture is presented in the next section; the method is described in the third section, followed by research results in the fourth section. The last section concludes and offers managerial and public policy recommendations.

\section{HOFSTEDE'S CONCEPT OF NATIONAL CULTURE}

Culture has no single and widely accepted definition. For the purpose of our research, we use the definition of culture as a "collective programming of the mind that distinguishes the members of one group or category of people from others" (Hofstede et al., 2010, p. 5), where the core of culture is formed by common values shared in the society. This is in line with de- 
DRUŠ. ISTRAŽ. ZAGREB GOD. 25 (2016), BR. 3, STR. 309-327

RAJH, E., BUDAK, J., ANIĆ, I.-D. HOFSTEDE'S CULTURE... fining culture as a pattern of shared values, beliefs and behaviours of a group of people (Kaasa et al., 2014). Culture pervades all aspects of life, frames societal perceptions (Hofstede, 2001) and has an impact on the behaviour of people (Gentina, Butori, Rose, \& Bakir, 2014). The term culture can be attributed to different nations, regions within nations, ethnic groups, occupations, organizations, and genders and age cohorts. Different approaches to analysing culture have been proposed in past research, and yet, the widely used concept in cross-cultural research is Hofstede's concept of national culture. It consists of five cultural dimensions: Power Distance, Individualism vs. Collectivism, Masculinity vs. Femininity, Uncertainty Avoidance, and Long-Term Orientation. Hofstede's concept of culture was developed based on a large survey database about values and related sentiments of matched populations of employees of the IBM Corporation in more than 50 countries around the world. Dimensions were extracted by using factor analysis of the data, and the validity of dimensions was tested using a variety of constructs and theories in social sciences. Dimensions can be measured by respective indices that are stable and can be used for cross-cultural comparisons. Major characteristics of the five dimensions are described in Table 1.

Hofstede's concepts are designed to assess national and organizational cultures of a society or societal group. There are various alternative methodologies for measuring national culture in the literature (e.g. Maznevski \& DiStefano, 1995; Triandis, 1989, 1995; Schwartz, 1999, 2012). Some of them might be an even better methodological choice because of their suitability for calculating measures on the individual respondent level (Yoo, Donthu, \& Lenartovicz, 2011), as Hofstede's cultural instrument lacks the validity to be employed at the individual units (Bearden, Money, \& Nevins, 2006; Blodgett, Bakir, \& Rose, 2008). Besides this limitation, there are serious controversies and critiques of the Hofstede concept (e.g. Fang, 2003; Jones, 2007). The discussion on the shortcomings and advantages of Hofstede's concept is not in the scope of this research. This paper offers a methodologically consistent analysis for Croatia, and as such might contribute to the future debate on this widely-used concept. In past research, Hofstede's concept was applied to compare the dimensions among numerous countries in the world (Hofstede et al., 2010; Kaasa et al., 2014). The concept was used in cross-cultural research to explain cross-cultural differences in consumer behaviour, business and organizational culture, managerial concepts and decision-making styles, company's behaviour, performance and innovation activities, (Durvasula, 
(1) TABLE 1

Major characteristics

of five cultural

dimensions
Lysonski, \& Andrews, 1993; Manrai \& Manrai, 2011; Budak et al., 2013; Gentina et al., 2014), and corporate financial policies as well (Chen, Dou, Rhee, Truong, \& Veeraraghavan, 2015).

Dimensions (indicators) / Major characteristics

Power Distance - It is defined as the extent to which less powerful members of institutions and organiza-

(PDI) tions within a society expect and accept that power is distributed unequally.

- In cultures with small Power Distance, bosses are not autocratic, subordinates and superiors consider themselves equal and subordinates easily approach and contradict their bosses. There is a preference for consultation. Organizations may be decentralized, while the gap in salaries might be low.

- In large Power Distance cultures, there is considerable dependence of subordinates on bosses. Subordinates are unlikely to approach and contradict their bosses. Organizations centralize the power and subordinates expect to be told what to do. There is a wide gap in salaries, while the superiors have privileges.

Individualism - It stands for a society in which the interests of the individual prevail over the interests of vs. Collectivism the group.

(IDV) - In more individualistic cultures, the job leaves employees sufficient personal time, they are free to adopt their own approach to the job, and get from the job a personal sense of accomplishment. Incentives and bonuses should be linked to an individual's performance, while poor performance of an employee might be the cause of firing. Rich countries score high on individualism, while poor countries usually score high on collectivism.

- In less individualistic cultures people are integrated into strong united groups, and economic life is organized by collectivistic interests. In collectivist societies, training, physical conditions and the use of skills are important. Employers might hire a person who belongs to a group. Incentives and bonuses are given to the group, not to individuals.

Masculinity - It refers to the degree to which values are associated with stereotypes of masculinity vs. Femininity (such as aggressiveness and dominance) and femininity (such as compassion, empathy, (MAS) and emotional openness).

- High masculinity cultures tend to have a stronger emphasis on achievement, earnings, recognition, advancement and challenge in jobs. People are more assertive and show less concern for individual needs and feelings. There are rich and poor masculine and rich and poor feminine countries.

- In feminine cultures, managers have a good relationship with employees, cooperation and employment security are highly valued. Conflicts are resolved by negotiations. Women are also managers. Employees like to live in the area which is desirable for them and their families. Feminine cultures have advantage in services, consulting, and transportation.

Uncertainty - Uncertainty Avoidance is defined as the extent to which members of institutions and Avoidance organizations in a society feel threatened by uncertain and unknown situations.

- In highly Uncertainty Avoidance societies people often feel nervous at work, company rules should not be broken, and they prefer stable jobs and a long-term career with a company. People stick to the rules, prefer a formal life structure and operate in seemingly predictable situations. Uncertainty-avoiding societies have more formal laws, more internal regulations and informal rules controlling work, rights and duties. Consumers in these societies are hesitant towards new products and information, and are slower in introducing communication tools.

- In weak Uncertainty Avoidance cultures, only the strictly necessary rules are acceptable. People tend to be more innovative and entrepreneurial.

Long-Term

- It stands for a society that fosters an orientation toward future rewards, persistence, thrift and savings. Wide economic differences are considered undesirable.

Orientation

- In countries with a long-term orientation, planning has a longer time horizon; companies are willing to make substantial investments in employee training and development.

- The short-term orientation, a typical western cultural characteristic, reflects values oriented toward the present and immediate short-term results. 
DRUŠ. ISTRAŽ. ZAGREB GOD. 25 (2016), BR. 3, STR. 309-327

RAJH, E., BUDAK, J., ANIĆ, I.-D HOFSTEDE'S CULTURE...
Several papers examined this concept in Russia, Belarus, Slovenia, Serbia, Macedonia, Bosnia and Herzegovina (BiH) (Avramska, 2007; Camina, 2000; Kustin, 2006; Milovanović, 2014; Podrug, Pavičić, \& Bratić, 2006; Prašnikar, Pahor, \& Vidmar Svetlik, 2008). As it considers studies of neighbouring countries and countries that might be interesting to compare the findings of our research with, they employed Hofstede's concept on part of the population, managers or for a narrowed and specific research purpose (e.g. Tavakoli, Keenan, \& Cranjak-Karanovic (2003) explored the nexus between culture and whistleblowing in Croatian companies). The common characteristic of past research is that these studies have used the VSM 94 survey module, which supports the methodology used in this research, described more in detail in the methodology section.

Although there are studies that support the idea of national clusters (Minkov \& Hofstede, 2012), the examination of within-country differences has just recently received more attention in the literature (Hofstede et al., 2010; Minkov \& Hofstede, 2014; Kaasa et al., 2014). Regional cultures refer to the diversity of cultures within the same country or to the similarities that may exist between geographical areas belonging, in legal terms, to several countries (Meier, 2004). A number of studies reveal a diversity of regional cultural variability among European countries (Kaasa et al., 2014), and claim that those differences exist due to variability in ethnic identity, historical background and geographical characteristics. The study of Kaasa et al. (2014) identified countries where within-country cultural variability is larger (Spain, Portugal, France) and smaller (Finland, Sweden and Norway) than cross-national variability. Also, in many countries a more detailed regional division brought out larger differences. Dolan, Díez-Piñol, Fernández-Alles, Martín-Prius, and Martínez-Fierro (2004) identified significant differences between two regions of one country (Spain), while Hofstede, Garibaldi de Hilal, Malvezzi, Tanure, and Vinken (2010) found remarkable within-country differences in Brazil. Somewhat puzzling findings on culture at the country and regional levels as well as the paucity of such research at regional level in transition countries, leads us to explore national and regional cultural characteristics in Croatia.

\section{METHOD}

In this research we applied Hofstede's Values Survey Module 1994 (VSM 94) which is a 26-item questionnaire developed for comparing culturally determined values of people from two or more countries or regions (Hofstede, 1994). Although two more recent versions of the similar questionnaire were developed, the VSM 94 module was chosen for several reasons. 
DRUŠ. ISTRAŽ. ZAGREB GOD. 25 (2016), BR. 3 STR. 309-327

RAJH, E., BUDAK, J., ANIC, I.-D. HOFSTEDE'S CULTURE...
According to the methodology explained by request on Hofstede's research resources site (http://geerthofstede.com/ research-and-vsm/vsm-08/), VSM 94 is suitable for regional comparisons "of geographical regions other than countries within one nation", which is the research goal of our paper. The latest VSM 2013 might be applied to geographical regions within a country, but in this case the questionnaire needs to be extended with locally relevant items, while this recommendation does not stand for VSM 94. Besides, the VSM 94 was used in other studies for neighbouring or comparable countries, so employing the same questionnaire for Croatia keeps the possibility to comment on the findings in future scholarly debates. The VSM 94 questionnaire has been used in the study of Požega, Crnković, and Gashi (2013) to analyse corporate culture in Croatian state-owned enterprises. Avramska (2007) explored cultural differences between business students in Macedonia, Kosovo and Slovenia by applying VSM 94. Nedeljković (2011) calculated indices for Serbia by using the VSM 94 instrument. The VSM 94 was used in the early 2000s for studies exploring organizational culture in Croatia and comparing it with other countries. Podrug et al. (2006) used VSM94 for cross-cultural comparison between three Central European countries, Croatia, $\mathrm{BiH}$ and Slovenia; and Tipurić, Podrug, and Hruška (2007) used the same module to examine the cultural differences in Croatia, Slovenia, $\mathrm{BiH}$ and Hungary. In their most recent research, Dabić, Tipurić, and Podrug (2015) compared Croatia, Slovenia, BiH and Hungary, and Podrug, Filipović, and Stančić (2014) conducted comparative research for Croatia, Brazil, Germany, Serbia and Spain, both using the VSM 94 instrument. All previous empirical studies support the argument that it is preferable to use the VSM 94 in calculating national culture indices for Croatia, following the procedures described below.

The VSM 94 module allows scores to be computed on five dimensions of national or regional culture, on the basis of four questions per dimension. The remaining six questions are demographic characteristics, including the respondent's gender, age, and education level, type of job, present nationality, and nationality at birth. Twenty content questions allow index scores to be calculated on five dimensions of national value systems as components of national cultures: Power Distance (PDI), Individualism (IDV), Masculinity (MAS), Uncertainty Avoidance UAI), and Long-Term Orientation (LTO).

Our survey was carried out in September 2014 on the nationally representative sample of 1,500 Croatian citizens. The market research agency Hendal was outsourced by the Institute of Economics, Zagreb, as the agency to conduct fieldwork activities. The survey was conducted by the CATI method (Computer Assisted Telephone Interviews). The 
DRUŠ. ISTRAŽ. ZAGREB GOD. 25 (2016), BR. 3, STR. 309-327

RAJH, E., BUDAK, J., ANIĆ, I.-D.:

HOFSTEDE'S CULTURE...

O TABLE 2

Summary statistics on sampled citizens, $\mathrm{N}=1,500$ response rate of above 36 percent - although this was not an issue because the net sample size was agreed with the agency - was satisfactory. The fieldwork covered the territory of the Republic of Croatia in terms of regions and settlement sizes, with telephone interviews being conducted in private households only. The target population was set to adult respondents, aged 18 to 64 . The nationally representative sample is based on a two-way stratification by 6 regions and 4 types of settlements by size, according to the 2011 Census. The structure of sampled citizens in terms of gender, age, education and region closely matches the corresponding share in the national population (Table 2). However, it is important to note that there is an underrepresentation of low-education respondents and overrepresentation of high-education respondents in our sample, which is known as a possible issue of telephone surveys Holbrook, Krosnick, \& Pfent, 2008).

\begin{tabular}{llccc}
\hline & & & $\begin{array}{c}\% \text { in } \\
\text { population* }\end{array}$ \\
\hline Gender & Males & $\mathrm{N}$ & $\%$ & 48.2 \\
& Females & 747 & 49.8 & 51.8 \\
& $18-24$ & 193 & 50.2 & 12.3 \\
& $25-34$ & 316 & 21.1 & 21.6 \\
& $35-44$ & 310 & 20.7 & 21.1 \\
\multirow{5}{*}{ Education } & 45-54 & 341 & 22.7 & 23.2 \\
& 55-64 & 337 & 22.5 & 21.7 \\
& 10 years and less & 150 & 10.0 & 21.3 \\
& 11-13 years & 802 & 53.5 & 52.3 \\
& 14 years and more & 548 & 36.5 & 26.4 \\
& North Croatia & 189 & 12.6 & 12.9 \\
& Central Croatia & 533 & 35.5 & 34.9 \\
& East Croatia & 283 & 18.9 & 20.1 \\
& South Croatia & 300 & 20.0 & 19.4 \\
& Istria and Primorje & 195 & 13.0 & 12.7 \\
\hline
\end{tabular}

*Cenzus 2011, http://www.dzs.hr

Five indices of national culture were calculated by using the following standard formulas (Hofstede, 1994):

$$
\begin{aligned}
& \text { PDI }=-35 \mathrm{~m}(03)+35 \mathrm{~m}(06)+25 \mathrm{~m}(14)-20 \mathrm{~m}(17)-20 \\
& \mathrm{IDV}=-50 \mathrm{~m}(01)+30 \mathrm{~m}(02)+20 \mathrm{~m}(04)-25 \mathrm{~m}(08)+130 \\
& \text { MAS }=+60 \mathrm{~m}(05)-20 \mathrm{~m}(07)+20 \mathrm{~m}(15)-70 \mathrm{~m}(20)+100 \\
& \text { UAI }=+25 \mathrm{~m}(13)+20 \mathrm{~m}(16)-50 \mathrm{~m}(18)-15 \mathrm{~m}(19)+120 \\
& \text { LTO }=-20 \mathrm{~m}(10)+20 \mathrm{~m}(12)+40
\end{aligned}
$$

Values for Hofstede's indicators range from 0 to 100 (although in some cases according to the formula, values could be negative or above 100). All five dimensions were calculated for Croatia as a whole and for every region in Croatia. 
DRUŠ. ISTRAŽ. ZAGREB GOD. 25 (2016), BR. 3 STR. 309-327

RAJH, E., BUDAK, J., ANIĆ, I.-D.

HOFSTEDE'S CULTURE...
Five Croatian regions were formed to present geographical and historical units adequate for exploring the cross-regional cultural differences in Croatia. Regional outer borders match county borders, so the administrative and territorial set-up is taken into account as well. Five spatial entities of North Croatia, Central Croatia, East Croatia, South Croatia, Istria and Primorje are elaborated according to the Marinović-Uzelac (2001) definition of region, that is homogenous in geographical (Kordej-De Villa \& Pejnović, 2014) and economic (Turčić \& Turčić, 2013) aspects. These regions were proposed in elaborating NUTS 2 regions in Croatia as presented in detail in Rašić (2003). The five regions examined in this study are graphically presented in Figure 1.

\section{(1) FIGURE 1 \\ Regions in Croatia}

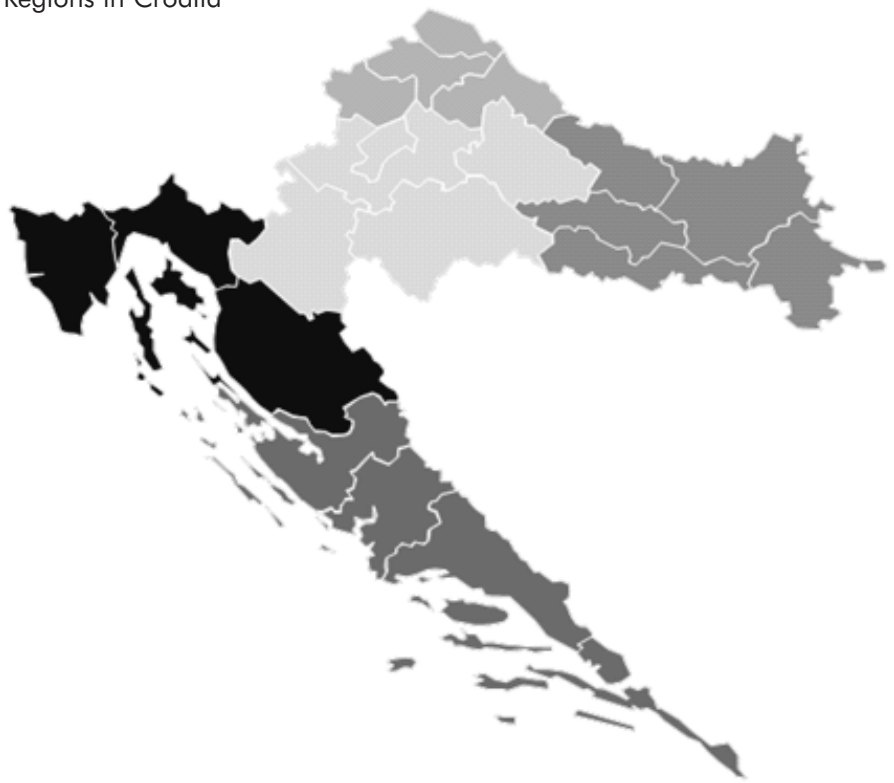

County of

Bjelovar-Bilogora

(City of) Zagreb

Sisak-Moslavina

Karlovac

Zagreb

Medjimurje

Varazdin

Koprivnica-Krizevci

Krapina-Zagorje

Sl. Brod-Posavina

Vukovar-Srijem

Virovitica-Podravina

Osijek-Baranja

Pozega-Slavonija

Primorje-Gorski Kotar

Lika-Senj

Istria

Dubrovnik-Neretva

Sibenik-Knin

Zadar

Split-Dalmatia
Region

1

1

1

1

2

2

2

3

3

3

3

3

4

4

4

5

5

5

5

Data were analysed by using the analysis of variance (ANOVA), Tukey post hoc test, t-test, chi-square test and K-means cluster analysis. 


\section{RESEARCH RESULTS}

Based on the survey data, we first calculated scores for five dimensions of national culture for Croatia as a whole (Figure 2).

$\rightarrow$ FIGURE 2

Hofstede's five cultural dimensions for Croatia, $\mathrm{N}=1,500$

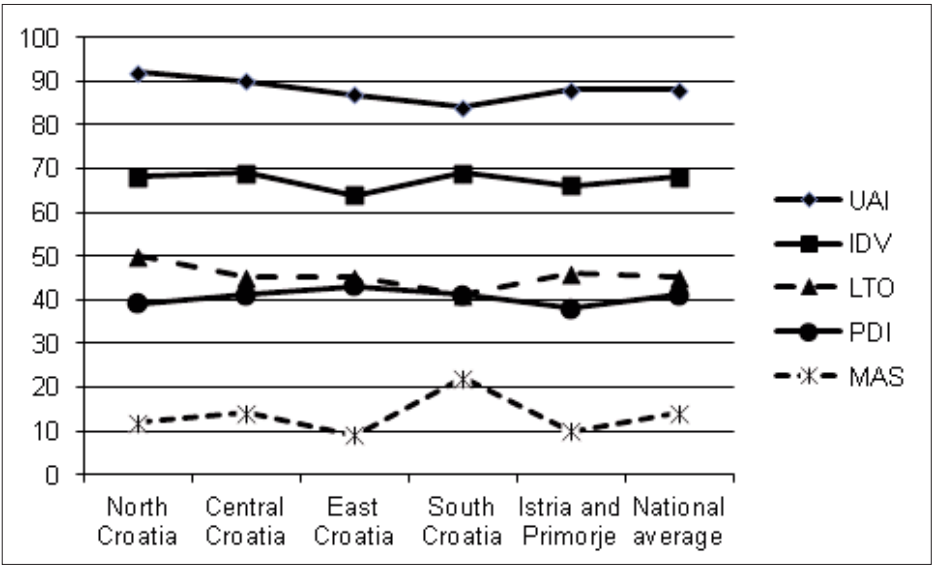

Note: ANOVA results: PDI $-\mathrm{F}=0.36, \mathrm{p}=0.837$; IDV $-\mathrm{F}=0.58$, $\mathrm{p}=0.687 ; \mathrm{MAS}-\mathrm{F}=0.90, \mathrm{p}=0.462 ; \mathrm{UAI}-\mathrm{F}=0.55, \mathrm{p}=0.700 ; \mathrm{LTO}-$ $\mathrm{F}=4.63, \mathrm{p}=0.001$

As can be seen, Croatia scores lower on PDI (PDI $=41$ ). This means that in such an environment bosses are not autocratic and employees would not hesitate to express their opinion to their supervisors. With respect to the IDV score, Croatia is a moderately high individualistic country with an IDV score of 68. In more individualistic cultures, employees have sufficient personal time besides their jobs, are free to adopt their own approach, and they get from the job a personal sense of accomplishment.

The MAS index is very low for Croatia (MAS = 14), which shows a prevalence of femininity over masculinity and implies a general preference for "soft and tender" values, for example, to achieve consensus in a decision-making process or to promote the welfare set of values and principles of solidarity. In such an environment, conflicts among individuals are resolved with negotiations.

The value of UAI is high (UAI = 88), which denotes a high aversion towards an ever-changing system and disorder in the society. High values of UAI also mean that people feel uncomfortable when facing ambiguous and unexpected situations, stress at work, and a lack of formal or informal rules. In these circumstances people prefer stricter rules and stability to avoid uncertainty.

The LTO index is rather low ( $\mathrm{LTO}=45)$, which suggests that the short-term orientation towards immediate and short- 
DRUŠ. ISTRAŽ. ZAGREB GOD. 25 (2016), BR. 3 STR. 309-327

RAJH, E., BUDAK, J., ANIC, I.-D. HOFSTEDE'S CULTURE... -term results is slightly prevailing in Croatia, and that long-term achievement of goals is somewhat less important to the population.

The next step in our analysis is the analysis of variance (ANOVA), which was used to determine regional differences (Figure 2). The analysis of variance results show that significant differences among regions existed only for the LTO dimension. Citizens from North Croatia exhibited higher levels of LTO, while citizens from South Croatia exhibited lower values of LTO (Tukey post hoc test is significant at $p<0.01$ ). The results further suggest that individuals in the observed regions share, in fact, similar values on four dimensions (out of five dimensions), which actually means that Croatian regions are quite homogenous with respect to cultural dimensions.

Considering that the observed variations in data cannot be explained by regions, we proceeded with t-test and the analysis of variance (ANOVA) to determine if there are differences in five cultural dimensions in terms of demographic characteristics of citizens (gender, age and education). The results show that significant differences exist for several cultural dimensions in terms of the analysed demographic characteristics (Table 3). Gender differences exist for MAS, UAI and LTO dimensions. Male respondents exhibited higher levels in MAS, while female respondents exhibited higher scores in UAI and LTO dimensions. Age differences were found in all five cultural dimensions, which indicates that age is the best demographic predictor of cultural dimension values. In terms of education, there are significant differences for PDI and IDV dimensions. The results indicate quite a linear relationship between the level of education and the level of both PDI and IDV. As the group has a higher level of education, it also exhibits higher levels of PDI and IDV. At the same time, these results show that the previously mentioned descriptive results, at least with regard to the PDI and IDV dimensions, should be taken with caution, because of an underrepresentation of low-education respondents and overrepresentation of high-education respondents in our sample.

In order to explore multi-variate relationships among cultural dimensions, region and demographic characteristics, we conducted K-means cluster analysis. Mean values of cultural dimensions at the individual level were taken as an input in $\mathrm{K}$-means cluster analysis. The percentage change in the heterogeneity criterion was used to determine the number of clusters in the dataset (Hair, Black, Babin, \& Anderson, 2010). $\mathrm{K}$-means cluster analysis produced four homogeneous segments of citizens based on their individual values of cultural dimension variables (Figure 3). 


\begin{tabular}{|c|c|c|c|c|c|c|}
\hline \multicolumn{2}{|c|}{ Demographic variables } & $\begin{array}{l}\text { PDI } \\
38\end{array}$ & $\frac{\mathrm{IDV}}{67}$ & $\frac{\text { MAS }}{25}$ & $\frac{\text { UAI }}{79}$ & $\frac{\mathrm{LTO}}{42}$ \\
\hline Gender & $\begin{array}{l}\text { Males } \\
\text { Females } \\
\text { t-test }\end{array}$ & $\begin{array}{l}38 \\
43 \\
t=1.57 \\
p=0.117\end{array}$ & $\begin{array}{l}67 \\
68 \\
t=0.31 \\
p=0.756\end{array}$ & $\begin{array}{l}25 \\
3 \\
t=4.87 \\
p=0.000\end{array}$ & $\begin{array}{l}79 \\
98 \\
t=5.22 \\
p=0.000\end{array}$ & $\begin{array}{l}42 \\
48 \\
t=4.66 \\
p=0.000\end{array}$ \\
\hline Age & $\begin{array}{l}18-24 \\
25-34 \\
35-44 \\
45-54 \\
55-65 \\
\text { ANOVA }\end{array}$ & $\begin{array}{l}33 \\
37 \\
47 \\
46 \\
37 \\
F=3.30 \\
p=0.011\end{array}$ & $\begin{array}{l}72 \\
75 \\
71 \\
60 \\
64 \\
F=5.13 \\
p=0.000\end{array}$ & $\begin{array}{l}37 \\
19 \\
8 \\
6 \\
11 \\
\mathrm{~F}=4.39 \\
\mathrm{p}=0.002\end{array}$ & $\begin{array}{l}86 \\
96 \\
88 \\
92 \\
90 \\
F=4.48 \\
p=0.001\end{array}$ & $\begin{array}{l}48 \\
48 \\
43 \\
44 \\
45 \\
F=3.31 \\
p=0.010\end{array}$ \\
\hline Education & $\begin{array}{l}10 \text { years and less } \\
11-13 \text { years } \\
14 \text { years and more } \\
\text { ANOVA }\end{array}$ & $\begin{array}{l}32 \\
38 \\
46 \\
F=5.54 \\
p=0.004\end{array}$ & $\begin{array}{l}59 \\
64 \\
75 \\
F=10.31 \\
p=0.000\end{array}$ & $\begin{array}{l}10 \\
15 \\
14 \\
F=0.23 \\
p=0.793\end{array}$ & $\begin{array}{l}87 \\
91 \\
84 \\
F=1.48 \\
p=0.228\end{array}$ & $\begin{array}{l}47 \\
44 \\
46 \\
F=1.84 \\
p=0.160\end{array}$ \\
\hline
\end{tabular}

(1) TABLE 3

Hofstede's cultural dimension scores by demographic characteristics, mean values, $N=1,500$

O FIGURE 3 Clusters of Croatian citizens based on Hofstede's five cultural dimensions, $N=1,500$

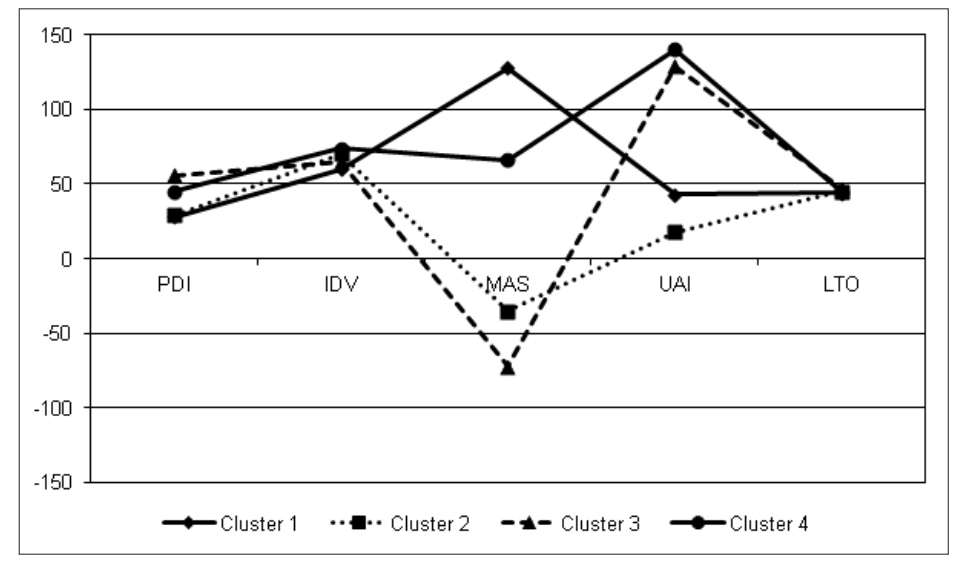

Note: Cluster 1: "Masculinity Pronounced", Cluster 2: "Risk Takers", Cluster 3: "Femininity Pronounced", Cluster 4: "Certainty Seekers". ANOVA results: $P D I-F=24.18, p=0.000 ; I D V-F=5.47, p=0.001$; MAS $-\mathrm{F}=1170.12, \mathrm{p}=0.000 ; \mathrm{UAI}-\mathrm{F}=708.36, \mathrm{p}=0.000 ; \mathrm{LTO}-\mathrm{F}=$ $0.92, \mathrm{p}=0.429$.

Citizens from Cluster 1, "Masculinity Pronounced", have the highest value of the MAS dimension. At the same time, they have one of the lowest values at the PDI and IDV dimensions. Citizens from Cluster 2, "Risk Takers", have the lowest value of UAI dimension and at the same time one of the lowest PDI values. Cluster 3, "Femininity Pronounced", exhibited the lowest score of the MAS dimension and one of the highest values at PDI and UAI dimensions. Citizens from Cluster 4, "Certainty Seekers", have the highest values of both UAI and IDV dimensions (Figure 3). 
DRUŠ. ISTRAŽ. ZAGREB GOD. 25 (2016), BR. 3 STR. 309-327

RAJH, E., BUDAK, J., ANIĆ, I.-D.

HOFSTEDE'S CULTURE...

(1) TABLE 4

Characteristics of clusters, Pearson's chi-squared test, $\mathrm{N}=1,500$
Pearson's chi-squared test was used to determine regional and demographic differences among the identified clusters (Table 4). The results indicate that significant differences existed in gender and age among the identified clusters, while there were no significant differences in region and education. After additional tests we did not find significant empirical evidence that there were regional differences in citizens' attitudes. Therefore, it may be concluded that Croatian regions are homogenous with respect to people's attitudes towards Hofstede's dimensions of national culture.

\begin{tabular}{|c|c|c|c|c|c|c|c|}
\hline & \multicolumn{6}{|c|}{ Cluster } \\
\hline & & $1(\%)$ & $2(\%)$ & $3(\%)$ & $4(\%)$ & Chi-square & $\mathrm{p}$ \\
\hline \multirow[t]{5}{*}{ Regions } & North Croatia & 13.5 & 9.6 & 14.5 & 12.9 & \multirow[t]{5}{*}{8.95} & \multirow[t]{5}{*}{0.707} \\
\hline & Central Croatia & 33.1 & 37.1 & 36.1 & 35.1 & & \\
\hline & East Croatia & 16.7 & 19.6 & 18.1 & 20.4 & & \\
\hline & South Croatia & 22.4 & 21.2 & 18.1 & 19.2 & & \\
\hline & Istria and Primorje & 14.2 & 12.5 & 13.3 & 12.4 & & \\
\hline \multirow[t]{2}{*}{ Gender } & Males & 62.3 & 53.9 & 40.0 & 47.5 & \multirow[t]{2}{*}{36.78} & \multirow[t]{2}{*}{0.000} \\
\hline & Females & 37.7 & 46.2 & 60.0 & 52.5 & & \\
\hline \multirow[t]{5}{*}{ Age } & $18-24$ & 18.5 & 15.1 & 8.0 & 12.7 & \multirow[t]{5}{*}{33.47} & \multirow[t]{5}{*}{0.001} \\
\hline & $25-34$ & 23.1 & 23.3 & 19.0 & 19.7 & & \\
\hline & $35-44$ & 18.9 & 20.2 & 23.4 & 19.7 & & \\
\hline & $45-54$ & 18.5 & 18.0 & 28.2 & 24.4 & & \\
\hline & $55-65$ & 21.0 & 23.3 & 21.5 & 23.7 & & \\
\hline \multirow[t]{3}{*}{ Education } & 10 years and less & 10.3 & 10.1 & 10.6 & 9.1 & \multirow[t]{3}{*}{6.47} & \multirow[t]{3}{*}{0.373} \\
\hline & $11-13$ years & 52.3 & 49.1 & 54.2 & 57.4 & & \\
\hline & 14 years and more & 37.4 & 40.9 & 35.2 & 33.5 & & \\
\hline
\end{tabular}

\section{CONCLUSIONS AND POLICY IMPLICATIONS}

The results of our analysis have some theoretical and practical implications. The first contribution of this study is the identification of Hofstede's five cultural dimensions in Croatia based on the sample of Croatian citizens. The results show that Croatia scores lower on Power Distance, is a predominantly individualistic country, has a tendency towards feminine culture, and has lower Long-Term Orientation, which are all characteristics of developed countries. This suggests that the process of rapid globalization and the advent of an information and knowledge-driven society have led to a convergence of peoples' attitudes close to the attitudes of people in developed countries. These trends are more evident among the younger generations as they are growing up in this new environment and are more susceptible to the new media and information they bring. 
DRUŠ. ISTRAŽ. ZAGREB GOD. 25 (2016), BR. 3, STR. 309-327

RAJH, E., BUDAK, J., ANIĆ, I.-D HOFSTEDE'S CULTURE...
Although not fully comparable, our results for national cultural dimensions could be interpreted in the context of the original data Hofstede produced for ex-Yugoslav countries regarding organizational culture (Hofstede, 2001). Here Podrug et al.'s (2006) estimates of Croatia's position in the 1991 scores are taken as a proxy for cultural dimensions recorded in the past.

Our study shows that the value of Uncertainty Avoidance is high in Croatia, which denotes a high aversion towards an ever-changing system and disorder in society, frequently facing ambiguous and unexpected situations. This is close to the past UAI index of 88 (Podrug et al., 2006), and also a characteristic of other post-transition economies that have, after the fall of the communist regime, virtually overnight embraced open market economies with many challenges, opportunities and threats (Kustin, 2006). Changes towards market society appeared overnight, but fear for the future remained, especially during the economic crisis which brought about a high unemployment rate.

Several managerial implications can be derived from our research results. Low PDI (and much lower than 25 years ago) means that employees still look for a relationship that is based on cooperation, where the power is decentralized and where the gaps in salaries are low. A higher and rising level of IDV suggests that companies can benefit from linking employees' interests with the interests of the company. Incentives and bonuses should be linked to an individual's performance, and this value is more expressed if compared to Podrug et al. (2006) scores (todays IDV $=68$, past IDV $=33$ ). Training programmes are, however, of a lesser degree of importance for the employees. The MAS index fell sharply from 40 in 1991 to 14 in 2015. A low level of the MAS index suggests that Croatian citizens prefer a good relationship with other employees, cooperation and employment security. Management should create such a working environment in which the conflicts are resolved by negotiations, team-work is appreciated and female management accepted. However, organizational policy should take into account that Croatians do not like to move to other locations, which might be needed due to the companies' restructuring programmes. Since Croatians show a higher level of UAI, it is recommended to create such a working environment in which stress is reduced, working tasks and procedures are transparent, and all phases of work are rule-regulated. People prefer stable and secure jobs. A higher level of UAI also shows why there are fewer innovations and why entrepreneurship is less successful in Croatia. Finally, with respect to LTO, Croatians are more oriented towards immediate and short-term results, and are less inter- 

GOD. 25 (2016), BR. 3 STR. 309-327

RAJH, E., BUDAK, J., ANIĆ, I.-D. HOFSTEDE'S CULTURE...
DRUŠ. ISTRAŽ. ZAGREB

ested in savings. The results might also have implications for designing a new regional policy in Croatia, according to EU standards.

Analysis at the regional level shows that individuals share similar values on four out of five dimensions across regions. Small differences in people's attitudes across regions show that Croatia is quite homogenous with respect to dimensions of culture. This study empirically supports the fact that it is better for cross-cultural research based on Hofstede's methodology, to take Croatia as a nation in cross-country comparisons, instead of at the sub-national level. This is in line with past research (Minkov \& Hofstede, 2012; Minkov \& Hofstede, 2014) and contributes to the policy debate on the regional set-up in Croatia. The regions analysed here are larger territorial units formed by grouping several counties together, and as such do not show regional cultural identities. In this context, the 21 counties in Croatia seem to be purely administrative territorial units and this needs to be further discussed.

This research has also some limitations. Methodologically, there is an underrepresentation of low-education respondents and overrepresentation of high-education respondents in our sample. Therefore, the results should be taken with caution, especially the results concerning the observed differences among groups with different education levels. Furthermore, average scores of Hofstede's cultural dimensions show a rather general picture of the set of values prevailing in Croatian society in context of business, and tell us little about other cultural values, beliefs and differences, in particular on the individual level. According to the five dimensions of national culture in Croatia, the differences among regions are not big enough to build distinctive social profiles of each region, and yet the regions cannot be defined on the basis of geographical characteristics only. One line of future research suggested is to add other elements of culture into the model and to use more qualitative approaches.

\section{REFERENCES}

Avramska, I. (2007). Cross-cultural comparison between business students from Macedonia, Kosovo and Slovenia and cultural differences in relation to economic development. (Master Thesis). University of Ljubljana, Faculty of Economics, Ljubljana. Available at http://www.cek.ef.uni-lj.si/ magister/avramska3163.pdf

Bačić, K., \& Šišinački, J. (2014). Croatia's potential for policentric development. Društvena istraživanja, 23(2), 327-347. doi:10.5559/di.23.2.06

Bearden, W. O., Money, B. R., \& Nevins, J. L. (2006). Multidimensional versus unidimensional measures in assessing national culture values: The Hofstede VSM 94 example. Journal of Business Research, 59(2), 195-203. doi:10.1016/j.jbusres.2005.04.008 
DRUŠ. ISTRAŽ. ZAGREB GOD. 25 (2016), BR. 3, STR. 309-327

RAJH, E., BUDAK, J., ANIĆ, I.-D.: HOFSTEDE'S CULTURE...
Blodgett, J., Bakir, A., \& Rose, G. M. (2008). A test of the validity of Hofstede's cultural framework. Journal of Consumer Marketing, 25(6), 339-349. doi:10.1108/07363760810902477

Budak, J., Rajh, E., \& Stubbs, P. (2013). Mind the gap: Citizens' and companies' views of business culture in Croatia. Croatian Economic Survey, 15(1), 89-114.

Camina, M. M. (2000). Research note: Cultural gaps in cross-national cooperation: The legacy of empires in Macedonia. Organization Studies, 21(1), 119-132. doi:10.1177/0170840600210008

Chen, Y., Dou, P. Y., Rhee, S. G., Truong, C., \& Veeraraghavan, M. (2015). National culture and corporate cash holdings around the world. Journal of Banking \& Finance, 50(1), 1-18. doi:10.1016/j.jbankfin.2014. 09.018

Dabić, M., Tipurić, D., \& Podrug, N. (2015). Cultural differences affecting decision-making style: A comparative study between four countries. Journal of Business Economics and Management, 16(2), 275-289. doi:10.3846/16111699.2013.859172

Dolan, S. L., Díez-Piñol, M., Fernández-Alles, M., Martín-Prius, A., \& Martínez-Fierro, S. (2004). Exploratory study of within-country differences in work and life values: The case of Spanish business students. International Journal of Cross Cultural Management, 4(2), 157-180. doi:10.1177/1470595804044747

Durvasula, S., Lysonski, S., \& Andrews, J. C. (1993). Cross-cultural generalizability of a scale for profiling consumers' decision-making styles. Journal of Consumer Affairs, 27(1), 55-65. doi:10.1111/j.17456606.1993.tb00737.x

Fang, T. (2003). A critique of Hofstede's fifth national culture dimension. International Journal of Cross Cultural Management, 3(3), 347-368. doi:10.1177/1470595803003003006

Gentina, E., Butori, R., Rose, G. M., \& Bakir, A. (2014). How national culture impacts teenage shopping behavior: Comparing French and American consumers. Journal of Business Research, 67(4), 464-470. doi:10.1016/j.jbusres.2013.03.033

Hair, J. F., Jr., Black, W. C., Babin, B. J., \& Anderson, R. E. (2010). Multivariate Data Analysis, 7th Edition. Upper Saddle River, New Jersey, USA: Prentice-Hall Inc.

Hofstede, G. (1980). Culture's consequences: International differences in work-related values. Beverly Hills CA: Sage Publications.

Hofstede, G. (1994). Values Survey Module 1994: Manual, VSM 94. Available by request at http://geerthofstede.com/research-andvsm/vsm-08/

Hofstede, G. (1997). Cultures and organizations: Software of the mind. New York: McGraw-Hill.

Hofstede, G. (2001). Culture's consequences: International differences in work-related values, 2nd Edition. Beverly Hills CA: Sage Publications.

Hofstede, G., Hofstede, G. J., \& Minkov, M. (2010). Cultures and organizations: Software of the mind. New York, USA: McGraw-Hill.

Hofstede, G., Garibaldi de Hilal, A. V., Malvezzi, S., Tanure, B., \& Vinken, H. (2010). Comparing regional cultures within a country: 
DRUŠ. ISTRAŽ. ZAGREB GOD. 25 (2016), BR. 3 STR. 309-327

RAJH, E., BUDAK, J., ANIC, I.-D. HOFSTEDE'S CULTURE...
Lessons from Brazil. Journal of Cross-Cultural Psychology, 41(3), 336-352. doi:10.1177/0022022109359696

Holbrook, A. L., Krosnick, J. A., \& Pfent, A. (2008). The causes and consequences of response rates in surveys by the news media and government contractor survey research firms. In J. M. Lepkowski, C. Tucker, J. M. Brick, E. de Leeuw, L. Japec, P. J. Lavrakas, M. W. Link, \& R. L. Sangster (Eds.), Advances in telephone survey methodology (pp. 499-678). Hoboken: John Wiley \& Sons.

Jones, M. (2007). Hofstede-culturally questionable? 2007 Oxford Business $\mathcal{E}$ Economics Conference. Availabe at http://www.gcbe.us/2007 OBEC/ data/confcd.htm

Kaasa, A., Vadi, M., \& Varblane, U. (2014). Regional cultural differences within European countries: Evidence from multi-country surveys. Management International Review, 54(6), 825-852. doi:10.1007/ s11575-014-0223-6

Kordej-De Villa, Ž., \& Pejnović, D. (2014). Interplay between demographic and regional development: Croatian case. In B. Angelova, D. Jurlina Alibegović, S. Redžepagic (Eds.), Contemporary trends and prospects of economic recovery (pp. 601-616). Nica, France: CEMAFI International.

Kustin, R. (2006). A study of Hofstede's culture value survey in a post-Soviet country: Perspectives from Belarus. Journal of Transnational Management, 11(4), 3-17. doi:10.1300/J482v11n04_02

Manrai, L. A., \& Manrai, A. K. (2011). Hofstede's cultural dimensions and tourist behaviors: A review and conceptual framework. Journal of Economics, Finance and Administrative Science, 16(31), 23-48. Available at http://www.scielo.org.pe/pdf/jefas/v16n31/a03v16n31.pdf

Marinović-Uzelac, A. (2001). Prostorno planiranje (Spatial planning). Zagreb: Dom i svijet.

Maznevski, M. L., \& Di Stefano, J. J. (1995). Measuring culture in international management: The cultural perspectives questionnaire. The University of Western Ontario Working Paper Series, pp. 95-39.

Meier, O. (2004). Management interculturelle. Dunod: Paris.

Milovanović, V. (2014). Uticaj nacionalne kulture na efekte sprovođenja menadžmenta ukupnog kvaliteta (The impact of national culture on total quality management effects). Megatrend Revija, 11(2), 183-200. Available at http://megatrendreview.naisbitt.edu.rs/files/ pdf/SR/Revija\%202-2014.pdf

Minkov, M., \& Hofstede, G. (2012). Is national culture a meaningful concept? Cultural values delineate homogeneous national clusters of in-country regions. Cross-Cultural Research, 46(2), 133-159. doi:10. 1177/1069397111427262

Minkov, M., \& Hofstede, G. (2014). Clustering of 316 European regions on measures of values: Do Europe's countries have national cultures? Cross-Cultural Research, 48(2), 144-176. doi:10.1177/106939711 3510866

Mooij, M., \& Hofstede, G. (2002). Convergence and divergence in consumer behavior: Implications for international retailing. Journal of Retailing, 78(1), 61-69. doi:10.1016/S0022-4359(01)00067-7 
DRUŠ. ISTRAŽ. ZAGREB GOD. 25 (2016), BR. 3, STR. 309-327

RAJH, E., BUDAK, J., ANIC, I.-D.: HOFSTEDE'S CULTURE..
Nedeljković, M. (2011). Organizational outcomes of the fitting between organizational structure and Hofstede's national culture indices, I International Symposium Engineering Management and Competitiveness 2011 (EMC2011), June 24-25, 2011, Zrenjanin, Serbia.

Podrug, N., Filipović, D., \& Stančić, I. (2014). Analysis of cultural differences between Croatia, Brazil, Germany and Serbia. Economic Research - Ekonomska istraživanja, 27(1), 818-829. doi:10.1080/1331677 X.2014.974915

Podrug, N., Pavičić, J., \& Bratić, V. (2006, October 12-13). Cross-cultural comparison of Hofstede's dimensions and decision-making style within CEE context. In From transition to sustainable development: The path to European integration, The Program Committee ICES2006 (Ed.) pp. 339-343. Sarajevo: School of Economics and Business, University of Sarajevo.

Požega, Ž., Crnković, B., \& Gashi, L. M. (2013). Analiza vrijednosnih dimenzija korporativne kulture zaposlenika poduzeća u državnom vlasništvu (Value dimensions of corporate culture of state-owned enterprise employees). Ekonomski vjesnik, 26(2), 391-400.

Prašnikar, J., Pahor, M., \& Vidmar Svetlik, J. (2008). Are national cultures still important in international business? Russia, Serbia and Slovenia in comparison. Management, 13(2), 1-26. Available at https:// www.efst.hr/management/Vol13No2-2008/1-Prasnikar\% 20Pa hor\%20Svetlik.pdf

Rašić, I. (2003). Introduction of nomenclature of territorial units for statistics in Croatia. Proceedings of 43rd Congress of the European Regional Science Association, Peripheres, Centres and Spatial Development in the New Europe, 27-30 August 2003, University of Jyväskylä, Jyväskylä, Finland / Local Organisation Committee (Ed.). Jyväskylä: Europen Regional Science Association, University of Jyväskylä.

Schwartz, S. H. (2012). An overview of the Schwartz theory of basic values. Online Readings in Psychology and Culture, 2(1). doi:10.9707/ 2307-0919.1116

Schwartz, S. H. (1999). A theory of cultural values and some implications for work. Applied Psychology: An International Review, 48(1), 23-47. doi:10.1111/j.1464-0597.1999.tb00047.x

Tavakoli, A. A., Keenan, J. P., \& Cranjak-Karanovic, B. (2003). Culture and whistleblowing. An empirical study of Croatian and United States managers utilizing Hofstede's cultural dimensions. Journal of Business Ethics, 43(1-2), 49-64. doi:10.1023/A:1022959131133

Tipurić, D., Podrug, N., \& Hruška, D. (2007). Cultural differences: Results from empirical research conducted in Croatia, Slovenia, Bosnia and Herzegovina and Hungary. The Business Review Cambridge, 7(1), 151-157.

Treven, S., Mulej, M., \& Lynn, M. (2008). The impact of culture on organizational behaviour. Management, 13(2), 27-39. Available at https://www.efst.hr/management/Vol13No2-2008/2-Treven\%20Mulej \%20Lynn.pdf

Triandis, H. C. (1989). The self and social behavior in differing cultural contexts. Psychological Review, 96(3), 506-520. doi:10.1037/0033295X.96.3.506 
DRUŠ. ISTRAŽ. ZAGREB GOD. 25 (2016), BR. 3, STR. 309-327

RAJH, E., BUDAK, J., ANIC, I.-D. HOFSTEDE'S CULTURE...
Triandis, H. C. (1995). Individualism and collectivism. Boulder: Westview Press.

Turčić, I., \& Turčić, I. (2013). Bruto domaći proizvod Republike Hrvatske po županijama i regijama 1990., 2000. i 2009. godine (Gross domestic product of the Republic of Croatia by counties and regions 1990, 2000 and 2009). Ekonomski pregled, 64(1), 64-81.

Yoo, B., Donthu, N., \& Lenartowicz, T. (2011). Measuring Hofstede's five dimensions of cultural values at the individual level: Development and validation of CVSCALE. Journal of International Consumer Marketing, 23(3), 193-210. doi:10.1080/08961530.2011.578059

\section{Primjena Hofstedeova upitnika kulture u Hrvatskoj: ispitivanje regionalnih razlika}

Edo RAJH, Jelena BUDAK, Ivan-Damir ANIĆ Ekonomski institut, Zagreb

Svrha ovog istraživanja jest primijeniti Hofstedeov upitnik nacionalne kulture $u$ Hrvatskoj i istražiti regionalne razlike $u$ stavovima hrvatskih građana o dimenzijama nacionalne kulture: distanca moći, individualizam, maskulinitet, izbjegavanje nesigurnosti i dugoročna orijentacija. $\mathrm{Na}$ temeliu ankete velikog uzorka građana u Hrvatskoj ( $N=$ 1500) analiziraju se vrijednosti za pet dimenzija na nacionalnoj razini i na razini regija. Ovo istraživanje pridonosi Hofstedeovoj teoriji kulture istraživanjem na cijeloj populaciij i time što se analiziraju regionalne razlike. Rezultati pokazuju da hrvatsku nacionalnu kulturu obilježava niža razina distance moći, umjereno viša razina individualizma, niska razina maskuliniteta i niža razina dugoročne orijentacije, što su sve karakteristike razvijenih zemalja. Čini se da je ubrzani proces globalizacije pridonio konvergenciji stavova građana i njihovu približavanju stavovima građana u razvijenim zemljama. Međutim, indeks izbjegavanja nesigurnosti visok je, što je karakteristika posttranzicijskih zemalja. Analiza na regionalnoj razini pokazuje da je Hrvatska homogena što se tiče stavova građana o dimenzijama kulture. Koristeći se dimenzijama nacionalne kulture u Hrvatskoj, provedena je klasterska analiza koja je pokazala razlike između klastera prema dobi i spolu te da nema značajnih razlika s obzirom na obrazovanje ispitanika. U radu se obrazlažu implikacije ovog istraživanja za menadžere i nositelje javne politike.

Ključne riječi: Hofstede, dimenzije kulture, Hrvatska, regionalne razlike 